DOI https://doi.org/10.18551/rjoas.2017-03.20

\title{
ADOPTION CHOICE OF SOIL ENHANCING MATERIALS BY RESOURCE POOR FARMERS
}

\author{
Etim Nsikak-Abasi A.*, Okon Sunday E. \\ Department of Agricultural Economics and Extension, University of Uyo, Uyo, Nigeria \\ Megbowon Ebenezer \\ Department of Agricultural Economics, University of Fort Hare, South Africa \\ *E-mail: boboetim@gmail.com
}

\begin{abstract}
The study examined the factors influencing the adoption choice of soil enhancing materials in Udung Uko, Akwa Ibom State, Nigeria. In a study conducted between July 2015 and December 2015, 100 resource poor farmers were sampled using the multi-stage sampling procedure. With the aid of questionnaire, primary data were obtained from the sampled farmers. Data were analysed using the multinomial logit model. Results of analysis indicated that sex, age, education, farm size, walking distance, extension and membership of social organization significantly influenced farmer's choice of soil enhancing materials. Intensifying programmes and formulating policies aimed at enhancing farmers choice of materials that will improve soil health would be a sensible and progressive option.
\end{abstract}

\section{KEY WORDS}

Adoption, soil enhancing materials, multinomial logit, farmers.

In Nigeria, arable farming is left mainly in the hands of small scale, resource poor farmers who cultivate between 1-2 hectares of farmland which are usually scattered over a wide area farmed with crude technologies (Obasi et al., 2013). But small scale farming in Nigeria particularly in Southern Nigeria is primarily constrained by continuous soil nutrient depletion which affects sufficient food production.

Agriculture has always relied on the human management of soil, plant nutrients and other natural means. Soil is the most important building block of a healthy, attractive landscape, and biological functions (Hochmuth et al., 2013). Soil health is fundamental asset for agricultural sustainability and is the most important part of any agricultural system (Pretty, 2002). Many cropping systems are under threat, unproductive, eroded or simply ignored during the process of agricultural intensification. Pretty (2002) and Etim (2015) food production in Africa suffers from numerous constraints, including diminishing useable land due to the dwindling water resources, climate variability unimproved planting materials, poor marketing and distribution system, poorly managed soils and above all high cost of agricultural inputs (Alfsen, 1997 and Agyekum et al 2014).

According to Farouque and Takeya (2007), a healthy resource base is essential to agriculture and the sectors ability to drive household and national economy and spur development. According to Pretty (2000), when soils are in poor health they cannot maintain productive agriculture. Providing sufficient food for the rapidly increasing population is a continuing challenge. Limited availability of cultivable land for crop production, coupled with declining yield growth has heightened concerns and interest about agricultures ability to feed its teeming population. But the scope for expanding the existing arable farmland inorder to meet the rising demand for food from a burgeoning population is limited. Therefore, inorder to meet the food and nutritional needs and ensure sustainable agricultural production, it is pertinent to produce sufficient food largely from the existing cropping lands. According to Doss (1994) and Alexandratos (1995), one way of doing this is by intensifying crop production and increasing crop yields.But sustainable agriculture starts with the soil by seeking to reduce soil erosion and to make improvements to soil physical structure, organic 
matter content, water-holding capacity and nutrient balances. Soil health is improved through the use of legumes, green manures and cover crops; the incorporation of plants with the capacity to release phosphate from the soil into rotations; the use of composts and animal manures; the adoption of zero-tillage; and the use of inorganic fertilizers where needed (Pretty, 2002). Consequently, adoption of suitable soil enhancing materials may help farmers to enhance crop production, increase yield and ensure sustainability. This study was therefore conducted to determine the factors that influence the adoption choice of soil enhancing materials by arable crop farmers.

\section{METHODS OF RESEARCH}

Study Area, sampling and Data Collection procedure. This study was conducted in Udung Uko Local Government of Akwa Ibom State, Nigeria. It lies between longitude and latitude with an estimated population of 53,278 people (NPC, 2006), Udung Uko is bounded to the North by Oron, to the West by Urue Offong Oruko and Okobo and to the East by Atlantic Ocean. The study area is in the rainforest zone and has two distinct seasons: the rainy and the short dry season. The annual precipitation ranges between $2000-3000 \mathrm{~mm}$ per annum. The predominant occupations of the people are farming and fishing.

The study employed two stage sampling procedure. First stage involved the purposive selection of 10 villages. The second stage involved the random selection of 8 households to make a total of 80 farming households.

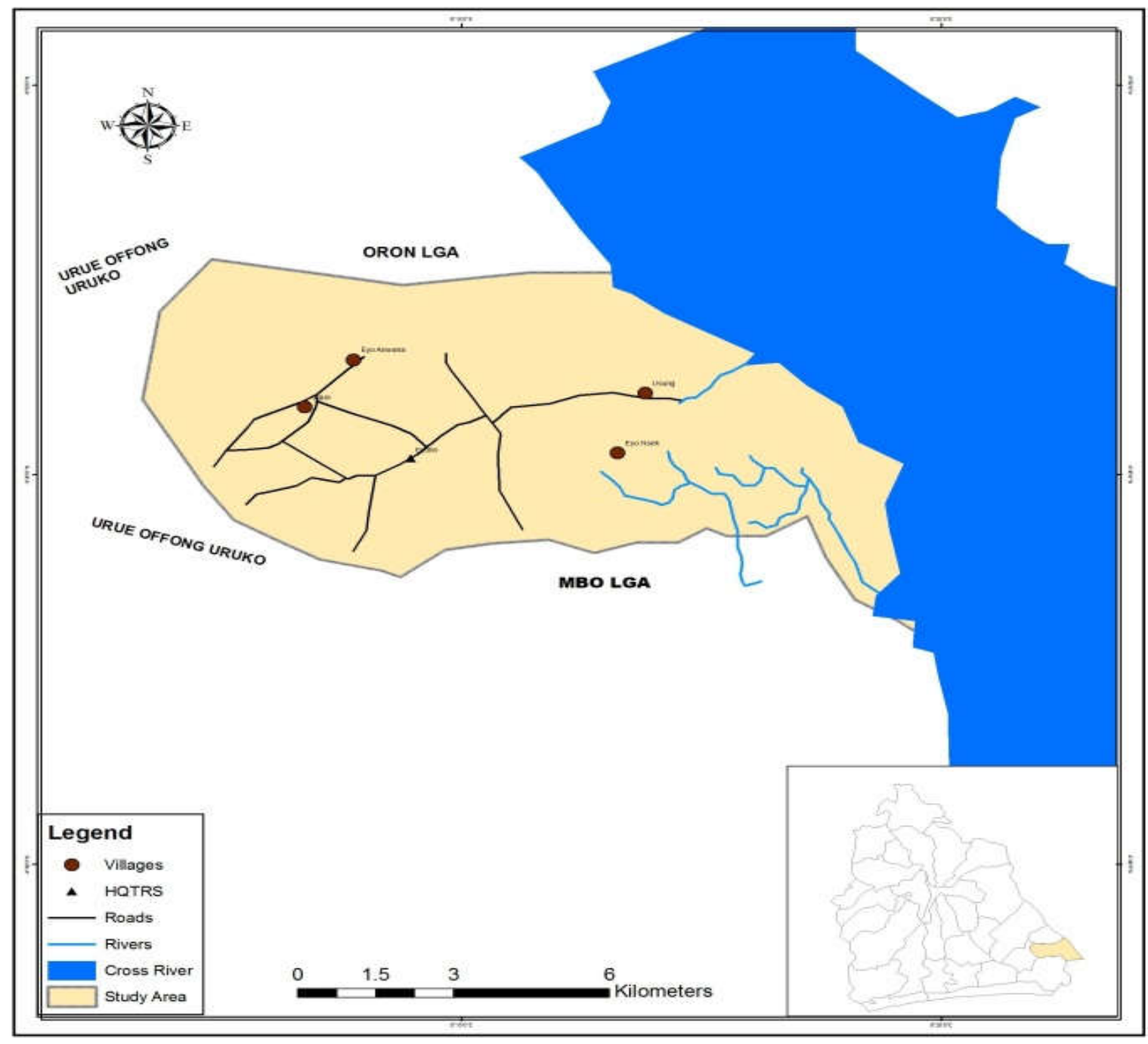

Figure 1 - Map of study location 
Model Specification. To model the determinants of soil enhancing materials (SEM) among arable crop farmers, Multinomial Logit Model (MNL)was used. The model is used to analyse the factors influencing choice of SEM among arable crop farmers in Udung Uko, Nigeria. The model was preferred because it permits the analysis of decisions across more than two categories in the dependent variable; hence it becomes possible to determine choice probabilities for the different SEMs. On the contrary, the binary probit or logit models are limited to a maximum of two choice categories (Maddala 1983). The MNL was preferred for this study because it is simple to compute than its counterpart, the multinomial probit model (Hassan and Nhemachena, 2008).

The MNL model is expressed as follows:

$$
\mathrm{P}(\mathrm{y}-\mathrm{j} / \mathrm{x})-/ \exp (\mathrm{X} \beta \mathrm{j}) /\left[1+\sum_{n=}^{j} \exp \left(x \beta_{n}\right) \mathrm{j} / 1,2, \mathrm{j}\right]
$$

Where: $y$ denote a random variable taking on the values $(1,2, \ldots . j)$ for a positive integer $\mathrm{J}$ and $x$ denote a set of conditioning variables. $X$ is a $1 \mathrm{xK}$ vector with first element unity and $\beta_{\mathrm{j}}$ is a $\mathrm{KX} 1$ vector with $\mathrm{j}=2, \ldots . \mathrm{j}$. In this case, $y$ denotes soil enhancing materials or categories while $x$ denotes specific household and farm characteristics of the arable crop farmers. The inherent is how changes in the household and farm specific characteristics affect the response probabilities $P(y=j / x), j=1,2, \ldots, j$. Since the probabilities must sum to unity, $p(y=j / x)$ is determined once the probabilities for $\mathrm{j}=1,2, \ldots, \mathrm{J}$ are known. For this study, the SEMs used in the study area were characterized, after which the most adopted material by farmers (or decision categories) were identified. These materials, comprised the decision categories for the multinomial logit model.

In order for the parameter estimates of the MNL model in Equation (1) to be unbiased and consistent, the independence of Irrelevant Alternatives (IIA) is assumed to hold (Deressa et al., 2008). The IIA assumption requires that the probability of using one SEM by a given arable crop farmer must be independent of the probability of choosing another SEM (that is $P_{\mathrm{j}} / \mathrm{P}_{\mathrm{K}}$ is independent of the remaining probabilities). The basis of this assumption is the independent and homoscedastic disturbance terms of the basic model in equation 1.

The parameter estimates of the MNL model only provide the direction of the effect of the explanatory variables on the dependent (choice) variable, thus the estimates represent neither the actual magnitude of change nor the probabilities. Instead, the marginal effects are used to measure the expected change in probability of a particular technique being chosen with respect to a unit change in an independent variable from the mean (Greene, 2000). To obtain the marginal effects for the model, equation 1 is differentiated with respect to the independent as shown in equation 2.

$$
\frac{\delta P_{j}}{\delta X_{k}}=\mathrm{P}_{\mathrm{j}}\left(\beta_{j k}-\sum_{J=1}^{J-1} P_{j} \beta_{j k}\right)
$$

It has also been observed that the marginal effects and respective coefficients may be different (Hassan and Nhemachena, 2008) since the former depends on the sign and magnitude of all the other coefficients.

The empirical specification for examining the influence of explanatory variables which are described in Table 1 on the choice of SEM $(Y)$ is given as follows:

$$
\begin{gathered}
Y=1 \ldots . j-/ \beta_{0}+\beta_{1}(\text { Sex })+\beta_{2}(\text { Age })+\beta_{3}(\text { Edu })+\beta_{4}(\text { Farm Size })+\beta_{5}(\text { Farming Exp })+\beta_{6}(\text { Walking Distance })+\beta_{7} \\
\text { (Extension })+\beta_{8}(\text { Land Tenure })+\beta_{9}(\text { Labour })+\beta_{10}(\text { Membership })+\beta_{11}(\text { Household Size })+\mu
\end{gathered}
$$

Where:

$y$ denotes a random variable taking on the values $(0,1,2,3,4)$ for no-negative integer $\mathrm{J}$;

$Y_{0}=$ Choice of zero soil enhancing material;

$Y_{1}=$ Choice of fertilizer;

$Y_{2}=$ Choice of poultry droppings;

$\mathrm{Y}_{3}=$ Choice of compost;

$\mathrm{Y}_{4}=$ Choice of wood ash. 
Test for Collinearity of Variables used in the Model. Multi-collinearity is one of the important econometric problems of cross sectional data analysis. In this study, multicollinearity was tested between the dependent variable and independent variables to ensure the consistency and unbiaseness of the multinomial logit model estimates. The variance inflation factor (VIF) was employed. The VIF has a minimum possible value of 1.0.Value greater than 10 indicates a probably collinearity problem between the dependent variable and the independent variables under consideration. VIF was estimated using the formula stated below:

$$
\text { VIF; } 1 /\left\{1-R_{j}^{2}\right\}
$$

Where: $R_{j}^{2}$ is the multiple correlation coefficient between dependent variable $\mathrm{j}$ and the independent variable under consideration.

Table 1 - Variable Used in the MNL Model and their Expected Signs

\begin{tabular}{llc}
\hline \multicolumn{1}{c}{ Variables } & \multicolumn{1}{c}{ Definition and Measurement } & $\begin{array}{c}\text { Expected } \\
\text { Sign }\end{array}$ \\
\hline SEM choice & Choice set of soil enhancing materials & \pm \\
Sex & Sex of the chief decision take (1= male, 0 = female) & \pm \\
Age & Age in years of the chief decision taker (continuous) & \pm \\
Education & Number of years of formal education of the household head & \pm \\
Farm size & Size of farmland available in hectares (continuous) & \pm \pm \\
Farming Exp. & Number of years of experience in farming of the household head & \pm \\
Walking & Walking Distance in kilometers to the nearest selling point of soil enhancing & \pm \\
Distance & materials(continuous) & \pm \\
Extension & Number of visits by extension agent (continuous) & \pm \\
contact & & \pm \\
Land Tenure & Land ownership by title deed (1 = owned by title deed, 0 =otherwise) \\
Labour & Labour in mandays employed in all farm operations (continuous) & \pm \\
Membership & If a farmer belong to agricultural related group & \pm \\
Household size & (1 = belong to a group, 0 = otherwise) & Number of household members (continuous) \\
\hline
\end{tabular}

\section{RESULTS AND DISCUSSION}

Test result for collinearity among specified variables in the Model Table 2 presents the VIF result for multicollinearity between the dependent variable and the explanatory variables used in the multinomial logit equation. The result revealed that there was no significant collinearity between the explanatory variables and the dependent variables in the model.

The result implies that the estimates of the Multinomial Logit Model have minimum variance, consistent and probably unbiased.

Table 2 - The variance inflation factors (VIF) test result for multicollinearity of variables used in the analysis

\begin{tabular}{ll}
\hline Variable & VIF estimates \\
\hline Age & 2.311 \\
Education & 3.185 \\
Farm Size & 1.924 \\
Farming Experience & 2.106 \\
Walking Distance to selling point of SEM & 3.141 \\
Labour & 4.532 \\
Household size & 2.067 \\
\hline
\end{tabular}

Descriptive Statistics. Figure 1 reveals that majority of the respondents (52.04 percent) were male whereas 47.96 attributable to the labour intensive and tedious nature of arable crop farming activities. Similar findings were obtained by Obisesan et al (2013) who studied the determinants of fertilizer use among smallholder food crop farmers. 


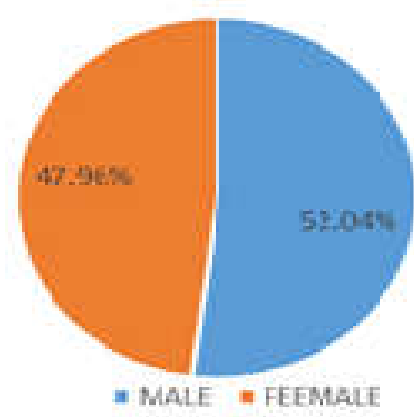

Figure 2 - Gender of Farmers

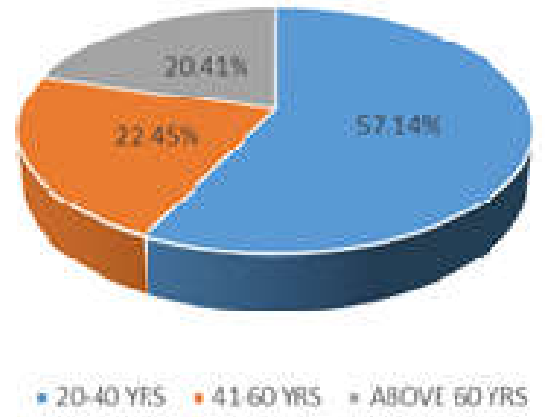

Figure 3 - Age of Farmers

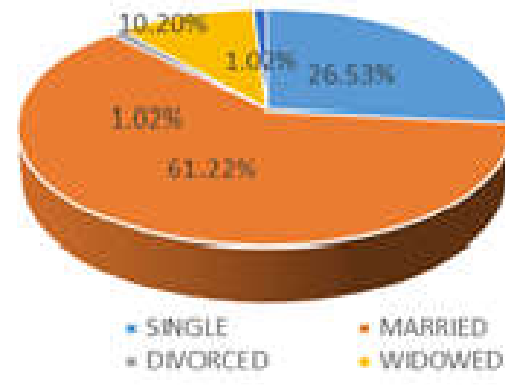

Figure 4 - Marital Status of Farmers

Most of the arable crop farmers (57.14) were within the age of 20-40 years implying that they were within the economically active and productive age. Result is synonymous with earlier empirical study by Edet and Etim, (2014) in their study of urban farming and its potentials for waste recycling.

About 61.22 percent by farmers were married as shown in figure 3 . Whereas only 26.53 percent were single, 10.20 percent were widows.

The educational background of the farmers is shown in figure 5 . The result revealed that most farmers (80.61 percent) had primary and post primary education. This is an indication that the farmers were literate and therefore were faster in the adoption of innovations.

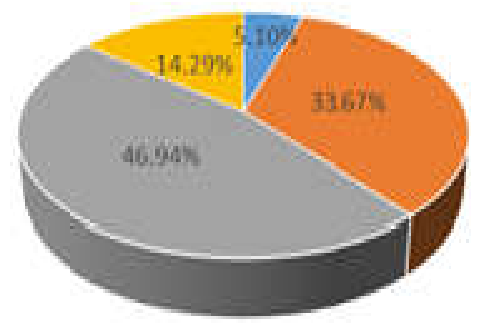

- NDSCHOOLING $\quad$ PII. SCHOOL

- SEC.SCHOOLI - TERTLARY SCH

Figure 5 - Education Status of Farmers

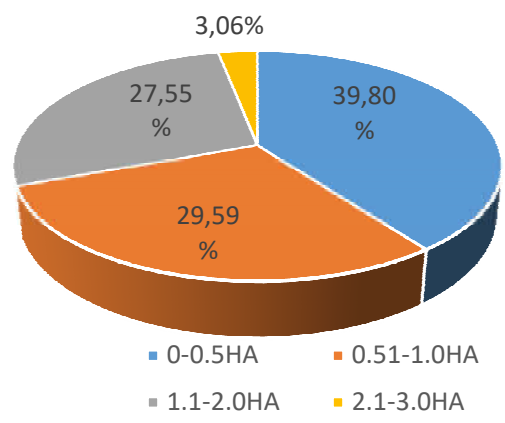

Figure 8 - Size of farmland

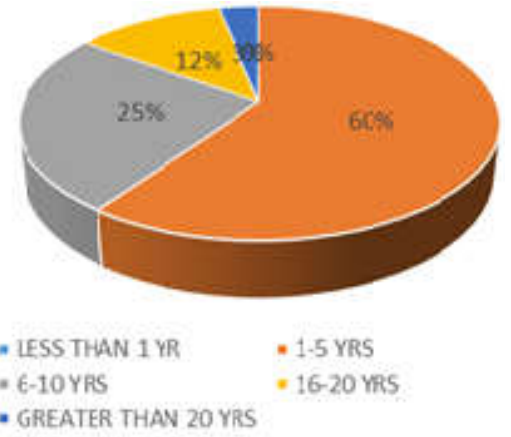

Figure 6 - Farming Experience

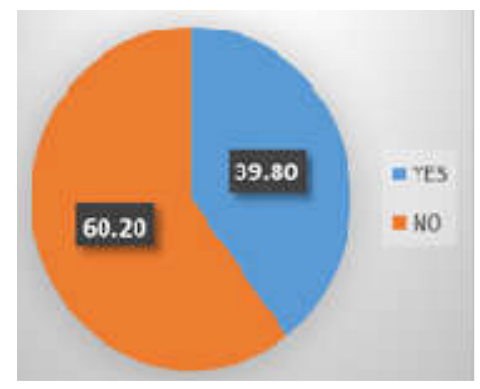

Figure 9 - Technology Adoption

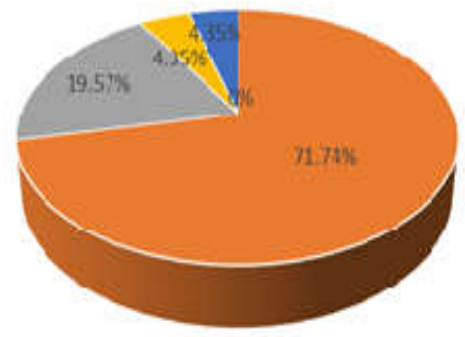

- LESS THAN 1YR $\quad$.15YRS

-6-10YRS $\quad$ 10-15YRS

- MDRETHAN 15 YRS

Figure 7 - Membership of Social Organization

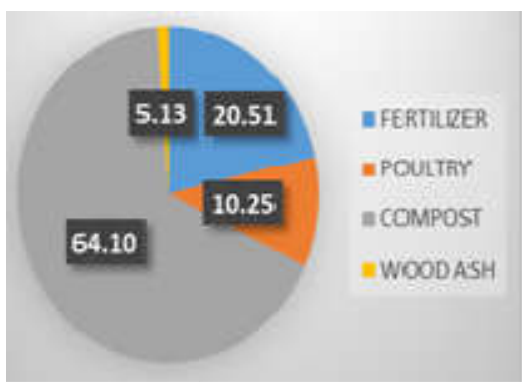

Figure 10 - Rate of Technology Adoption

The experience of farmers in arable crop farming is shown in figure 6 . Majority of the farmers (56.12 percent) had between 1-5 years experience in farming whereas 23.47 percent had 6-10 years experience in farming. About 20.40 percent had between 11-20 years 
experience in arable crop farming. Result suggest that the reason for the low number of years in arable crop farming may be attributable to the fact that fishing activities are also majority undertaken being a coastal community.

Figure 7 shows that most $(71.74 \%)$ of the crop farmers had between $1-5$ years standing as members of social organization whereas $4.35 \%$ had between $10-15$ years standing as members of social organization.

The size of farmland of farmers is shown in figure 8. Most of the farmers (69.39) percent cropped farmlands that were less than 1 hectare whereas 30.61 percent cropped farms between 1-2 hectares. Result suggest that majority of respondents were subsistence farmers who cultivated small farm holdings mainly for family consumption. This result is in conformity with earlier empirical findings by Etim and Edet (2013) in their study of adoption of inorganic fertilizer by Resource poor cassava farmers in Nigeria.

Determinants of Adoption of Soil Enhancing Materials. Figure 9 shows that the adoption of innovation was 60.20 percent while 39.80 percent of the farmer did not adopt new technology.

Figure 10 shows that rate of adoption of the different soil enhancing materials. From the figure, the most adopted SEM (compost) was 64.10 percent, followed by fertilizer, 20.51 percent, poultry dropping (10.25 percent) and wood ash (5.13 percent).

Table 3 - Marginal effects from the multinomial logit on the choice of SEM

\begin{tabular}{|c|c|c|c|c|c|c|c|c|c|c|}
\hline \multirow[t]{2}{*}{ Explanatory variables } & \multicolumn{2}{|c|}{ No adoption } & \multicolumn{2}{|l|}{ Fertilizer } & \multicolumn{2}{|c|}{ Poultry droppings } & \multicolumn{2}{|l|}{ Compost } & \multicolumn{2}{|c|}{ Wood ash } \\
\hline & $\delta x / \delta y$ & $\begin{array}{l}\text { P- } \\
\text { level }\end{array}$ & $\delta x / \delta y$ & P-level & $\delta x / \delta y$ & $\begin{array}{l}\text { P- } \\
\text { level }\end{array}$ & $\delta x / \delta y$ & $\begin{array}{l}\text { P- } \\
\text { level }\end{array}$ & $\delta x / \delta y$ & $\begin{array}{l}\text { P- } \\
\text { level }\end{array}$ \\
\hline Sex & 0.0621 & 0.284 & $\overline{0.1019 * *}$ & 0.007 & 0.0471 & 0.144 & 0.0631 & 0.002 & 0.3102 & -0.032 \\
\hline Age & $0.0224^{* *}$ & 0.081 & $0.0115^{\star}$ & 0.061 & 0.0160 & 0.025 & $-0.0143^{*}$ & 0.020 & 0.1033 & 0.510 \\
\hline Education & 0.0153 & 0.371 & $0.0082^{*}$ & 0.120 & 0.1272 & 0.036 & 0.0053 & 0.120 & 0.0701 & 0.060 \\
\hline Farm Size & 0.0711 & 0.062 & $0.1233^{*}$ & 0.032 & $0.1013^{* *}$ & 0.058 & 0.1022 & 0.202 & 0.1001 & 0.080 \\
\hline Farming experience & 0.0321 & 0.010 & 0.0612 & 0.512 & 0.2010 & 0.416 & 0.1008 & 0.406 & 0.2002 & 0.163 \\
\hline Walking Distance & 0.1423 & 0.042 & 0.0317 & 0.073 & 0.0340 & 0.610 & $-0.0637^{\star *}$ & 0.043 & 0.0074 & 0.009 \\
\hline Extension & $-0.1703^{*}$ & 0.021 & $0.0251^{* *}$ & 0.0023 & 0.0251 & 0.812 & 0.0810 & 0.510 & 0.0601 & 0.320 \\
\hline Land Tenure & 0.0752 & 0.001 & 0.0078 & 0.718 & 0.0062 & 0.306 & 0.0310 & 0.308 & 0.1230 & 0.030 \\
\hline Labour & 0.0038 & 0.035 & 0.0521 & 0.322 & 0.1611 & 0.201 & 0.1510 & 0.005 & 0.2014 & 0.004 \\
\hline $\begin{array}{l}\text { Organisation } \\
\text { Membership }\end{array}$ & -0.0236 & 0.370 & $0.0481^{* *}$ & 0.106 & 0.1502 & 0.210 & $0.1377^{* *}$ & 0.018 & 0.0055 & 0.001 \\
\hline
\end{tabular}

Table 3 presents the results of the multinomial Logit Model in which 7 out of 10 variables used in the model were statistically significant. The chi-square value of 103.043 revealed that the likelihood ratio statistics are highly significant alluding that the model has a strong explanatory power. The Pseudo-R-square was 0.7450 signifying the explanatory variable explained about $74.5 \%$ of the variation in choice of SEM.

Sex of the household head had been significant on the choice of poultry dropping and fertilizer at $1 \%$ and $5 \%$ level respectively. Male-headed households had a higher probability of using poultry droppings by $4.71 \%$. Conversely, the probability of using fertilizer was lower by $10.19 \%$ for male-headed households. This may not be unconnected with the fact that male-headed households are risk takers and have a higher accessibility to resources and information which give them ability to adopt new ideas than the female-headed households who are hunted by social and traditional constraints (Kaliba et al 2000; Asfaw and Admassie, 2004; Obeudo et al 2009; Ayuya et al., 2012).

The results revealed that age of the household head significantly influenced the probability of not choosing to use any SEM at $5 \%$ level. Age also significantly influenced the likelihood of choosing to use fertilizer and compost at 1\%. An increase in age of the household head by one year increased the likelihood of not using any of the SEM by $2.24 \%$ and use of fertilizer by $1.15 \%$. However, increase in age by one year decreased the probability of choosing compost by $1.43 \%$. Result suggests that younger household heads are more interested in trying out new ideas and technologies due to their risk taking nature.

Education level of the household head was significant and had a direct effect on choice of fertilizer. An increase in education level by 10 years increased the probability of choosing 
to use fertilizer by $8.2 \%$. This result is consistent with earlier findings by Feder et al. (1985), Udoh and Etim (2006; 2008; Etim and Okon (2013); Etim and Edet (2013); Etim (2015) who found that higher education empowers farmers to interprete and respond to new information and ideas much faster than their counterpart with lower education. This result also supports the hypothesis that human capital plays a positive role in the acquisition and evaluation of new ideas. The result is in conformity with findings by Nkamleu and Adesina, (2000) in Cameroon; Bacha et al. (2001) and Zegeye (2001) in Ethiopia; Chirwa (2005) in Malawi; Chianu and Tsujii (2004) and Etim (2015) in Nigeria.

The choice of using fertilizer and poultry dropping was positively and significantly influenced by the size of farm land. Increasing the size of farm by one hectare increases the probability of choosing to use fertilizer and poultry dropping by $12.33 \%$ and $10.13 \%$ respectively. Result implies that small holdings of farmland typically do not encourage the use of technology. Larger farms give room for the experimentation of technology on a small plot of larger lands without fear of compromising the family food security. According to Zepeda (1994), the benefits derivable from large scale adoption of innovation or new technologies are higher for larger farms. Results are synonymous with earlier empirical findings by Abara and Singh (1993); FernandezCornejo (1996), Adesina (1996), Onyenweaku et al (2010), Etim and Edet (2014) and Etim (2015) who variously documented the positive effect of increasing farm size on technology adoption.

The distance of farms from farmers homes was significant and negatively related the choice of compost $(\mathrm{P}<0.05)$. This implies that an increase in farm distance by one kilometer reduced the probability of choosing compost by $6.37 \%$. This may not be unconnected with the labourers task of compost preparation and transportation to farms that are farer from homesteads. Finding is synonymous with earlier empirical results of Ayuya et al (2012). Studies by Chukwuji and Ogisi (2006) Alene et al (2008) ; and Olowale et al (2009) however agree that farms located closer to homesteads have a positive influence on the adoption of new ideas.

The choice of non-adoption was significantly influenced by the frequency of extension contact. This implies that an increase in extension contact by one visit decreased the probability of choosing non-adoption of SEM by $17.03 \%$. An increase in the frequency of extension contact increased the probability of using fertilizer by $2.51 \%$. Studies by Adesina et al (2000), Abdulai and Huffman (2005); Menale et al (2009); Tizale (2007); Yirga (2007) variously documented that frequency of extension contacts being a proxy for farmers' access to agricultural information, positively affected awareness and adoption of new technologies.

Membership of social organization positively influenced the choice of fertilizer and compost at $5 \%$ level of significance. Farmers who are members of agriculturally related social organizations had a higher probability of choosing fertilizer and compost by $4.81 \%$ and $13.77 \%$ respectively. This is attributable to the fact that with socialization, farmers are exposed to a broad range of ideas, knowledge and information. According to Nkamleu (2007), membership in social groups exposes farmers to a wide range of ideas and sometimes gives farmers the opportunity to better access information, through training and extension services, which may positively change their attitude towardsan innovation. This result corroborates earlier finding by Nchinda et al (2010) and Anyuya et al (2012) that a positive relationship exist between group membership and the adoption of fertilizer.

\section{CONCLUSION AND POLICY RECOMMENDATION}

The study was conducted to analyze the factors influencing resource poor arable crop farmers' choice of soil enhancing materials. The multinomial logit model was employed to analyse the data. Results of analysis revealed that the most critical factors influencing farmers' choice of materials likely to improve the soil health were sex, age, education, farm size, walking distance, extension and social group membership. Policies aimed at improving farmers choice of soil improving materials should be pursued. 


\section{REFERENCES}

1. Abara I.O.C. and Singh S., (1993). "Ethics and Biases in Technology Adoption: The Small Farm Argument" Technology Forecasting and Social Change, 43:289-300.

2. Abdulai, A. and W. E. Huffman (2005). The diffusion of new agricultural technologies: The case of crossbred-cow technology in Tanzania. American Journal of Agricultural Economics 87:645-659.

3. Adesina A. A. (1996). Factors Affecting the Adoption of Fertilizer by Rice Farmers in Cote d'Ivoire. Nutrient Cycling in Agro-Ecosystems;46:29-39.

4. Adesina, A. A., Mabila, D., Nkamleu, G. B. and Endamana, D. (2000). Econometric analysis of the determinants of adoption of alley farming by farmers in the forest zone of Southwest Cameroon. Agric Ecosyst. Environment. 80:255-265.

5. Agyekum E. O., Ohere-Yankyere K., Keraita B., Fialor S. C. and R. C. D. (2014). Willingness to Pay for Food Faed Compost by Farmers in Southern Ghana. Journal of Economics and Sustainable Development. 5(2):18-25.

6. Alene, A. D., Manyong, V. M., Omanya, G., Mignouna; Bokanga, H. D., and G. Odhiambo (2008). Smallholder market participation under transaction costs. Maize supply and fertilizer demand in Kenya. Food Policy 33: 318-328.

7. Alexandrators, N. (1995). World Agriculture: Towards 2020. An FAO study. Food and Agriculture Organization in United Nations, Italy,Rome.

8. Alfsen, K. B. (1997). Soil Degradation and Economic Development in Ghana. Environment and Development Economics; 191-203.

9. Asfaw, A. and Admassie (2004). The role of education on the adoption of chemical fertilizer under different socio economic environments in Ethiopia. Agric. Econ, 30(3):215228.

10. Aye G. C. and Mungatana E. D. (2010). Technical Efficiency of Traditional and Hybrid Maize Farmers in Nigeria: Comparison of Alternative Approaches. African Journal of Agricultural Research; 5(21)2909-2917.

11. Ayuya, O. A., Lagat, J. K. and J. M. Mironga (2011). Factors influencing potential acceptance and adoption of clean development mechanism projects: Case of carbon trade tree project among small scale farmers in Njoro District, Kenya. Res. J. Env. Earth Sci. 3(3): 275-285.

12. Bacha, D. Aboma G., Gemeda A. and De Groote H. (2001). The Determinants of fertilizer and manure use in maize production in Western Oromiya, Ethiopia. Seventh Eastern and Southern Africa Regional Maize Conference, 11-15 February, Pretoria.

13. Chianu J. N. and Tsujii, H. (2004). Determinants of farmers' decision to adopt or not adopt inorganic fertilizer in the savannas of northern Nigeria. Nutrient Cycling in Agro ecosystems, 70(3):293-301.

14. Chirwa E. W. (2005). Adoption for fertilizer and hybrid seeds by smallholder maize farmers in southern Malawi Development Southern Africa 22(1) 1-12.

15. Chukwuji, O. C. and O. D. Ogisi (2006). A tobit analysis of fertilizer adoption by smallholder cassava farmers in Delta state, Nigeria. Agricultural Journal 1(4): 240-248.

16. Deressa, T., R. M. Hassan, T. Alemu, M. Yesuf and C. Ringler (2008). An Analysis of Determinants of Farmer's Choice of Adaptation Methods and Perceptions. International Food Policy Research Institute, Washington, DC. P.2.

17. Doos, R. D. (1994). Environmental Degradation, Global Food Production and Risk for Large Scale migrations. Ambio 23(2): 124-130.

18. Edet, G. E. and Etim, N. A. (2014). Urban Farming and its Potentials for Waste Recyclying. American Journal of Social Sciences 2(1): 16-20.

19. Etim N.A., Edet G.E. (2014). Factors Determining Urban Poverty of Farming Households in a Tropical Region.AmericanJournal of Experimental Agriculture, 4(3):322-335.

20. Etim N. A. and Udoh E. J (2014). Identifying Sources of Efficiency among Resource Poor Indigenous Vegetable Farmers in Uyo, Nigeria. International Journal of Food and Agricultural Economics, 2(1)33-39. 
21. Etim N. A. and Udoh E. J. (2013). The Determinants of Rural Poverty in Nigeria. International Journal and Agricultural Management and Development 3(2):141-151.

22. Etim N. A., Thompson D. and Onyenweaku, C. E. (2013). Measuring Efficiency of Yarn (Dioscorea spp) Production among Resource Poor Farmers in Rural Nigeria. Journal of Agricultural and Food Sciences, 1(3):42-47.

23. Etim N.A. and Okon S. (2013). Sources of Technical Efficiency among Subsistence Maize Farmers in Uyo, Nigeria. Journal of Agricultural and Food Science 1(4):48-53.

24. Etim, N. A. and Edet, G. E. (2013). Adoption of Inorganic fertilizer by Resource Poor Cassava Farmers in Niger Delta Region, Nigeria. International Journal of Agricultural Innovations and Research, 2(1):94-98.

25. Etim, N. A. (2015). Adoption of Inorganic Fertilizer by Urban Crop Farmers in Akwa Ibom State, Nigeria. American Journal of Experimental Agriculture, 5(5):466-474.

26. Farouque, M. G. and Takeya, H. (2007). Resources Poor Farmers' Constraints regarding Integrated Soil Fertility and Nutrient Management for Sustainable Crop Production. A farm level study in Bangladesh. A paper poster prepared for presentation at the 106th seminar of the EAAE. Pro-poor develop'ment in low income countries. Food, agriculture, trade and environment 25-27 October, 2007. montPellier France.

27. Feder G. et al (1985). The adoption of Agricultural Innovations in developing countries a survey. Economic Development and Cultural Change; 32(2):255-98.

28. Fernandez-Cornejo J. (1996). "The Microeconomic impact of 1PM Adoption: Theory and Application". Agricultural and Resource Economic Review; 149-160.

29. Freeman H. A. and Omiti J. M. (2003). Fertilizer use in semi-arid areas of Kenya. Analysis of smallholder farmers' adoption behavior under liberalized markets Nutrient Cycling in Agro ecosystems, 66(1): 23-31.

30. Greene, W. H. (2000). Econometric Analysis 5TH Ed. Prentice Hall, New Jersey.

31. Hassan, R. and Nhemachena C. (2008). Determinants of African Farmer's Strategies for adapting to climate change: Multinomial Choice analysis. Afr. J. Agric. Res. 2(1):83-104.

32. Hochmuth G., Trenholm, L., Momod, E., Rainey, D., Lewis, C. and Bram, N. (2013). The Role of Soil Management in Minimising Water and Nutrient Losses from the Urban Landscape. A Joint publication of Multiple Departments and Programs in UF/IFAs.

33. Kaliba, A. R. M., Verkuijl, H. Mwangi, W., Byamungu, D. A., Anadajayasekeram and A. J. Moshi. (2000). Adoption of maize production technologies in intermediate and lowlands of Tanzania. J. Agric Econ. 32(1) 35-47.

34. Khai H. V, Yabo M., Yokogawa H. and State G. (2008). Analysis of Productive Efficiency of Soya bean Production in the Mekong River Delta of Vietnam J. Faculty Agric Kyushn University. 53(1):271-279.

35. Maddala, G. S. (1983). Limited Dependent and Qualitative Variables in Econometrics.Econometrics Society Monographs. Cambridge University Press, Cambridge.

36. Menale, K., Zikhali, P., Kebede, M. and Edwards, S. (2009). Adoption of Organic Farming techniques: Evidence from a Semi-Arid Region of Ethiopia Environment for Development EFD DP 09-01.

37. NPC (National Population Commission) 2006: "Population Census of the Federal Republic of Nigeria". Analytical Report at the National Population Commission, Abuja.

38. Nchinda, V. P., Ambe T. E., Holvoet, N. Leke., W. Che, M. A., Nkwate, S. P. and S. B. Ngassam. (2010). Factors influencing the adoption intensity of improved yam (Dioscorea spp). Seed technology in the Western highlands and high guinea savannah zones of Cameroon. J. Appl. Bio 36:2389-2402.

39. Nkamleu G. B and Adesina A. A. (2000). Determinants of chemical input use in periurban lowland systems. Bivariate probit analysis in Cameroon. Agricultural Systems, 63: 111-121.

40. Obasi, P. C., A. Henri-Ukoha and I. S. Ukewihe (2013).Factors Affecting Agricultural Productivity among Arable Crop Farmers in Imo State, Nigeria. American Journal of Experimental Agriculture 3(2): 443-454. 
41. Obendo, M., Obase, G. and Salasya, B. (2009). Factors responsible for differences in uptake of integrated soil fertility management practices amongst smallholders in Western Kenya. Afri. J. Agric. Res. 4(11):1303-1311.

42. Obisesan, A. A., Akinlade R. J. and F. O. Fajimi (2013). Determinants of Fertilizer use Among Smallholder Food Crop Farmers in Ondo State, Nigeria. American Journal of Research Communication 1(7):254-260.

43. Olawale, E. O., Arega, D. A. and A. Ikpi (2009). Determinants of fertilizer use in Northern Nigeria. Pakistan Journal of Social Science 6(2): 91-98.

44. Onyenweaku C. E., Okoye B. C. and Okorie K. C. (2010). Determinants of Fertiliser Adoption by Rice Farmers in Bende Local Government Area of Abia State, Nigeria. The Nigerian Agricultural Journal. 41(2):1-6.

45. Pretty, J. (2002). "Agriculture, Reconnecting People Land and Nature". Earthscan Publications Limited, London, Sterling, V. A.

46. Tizale, C. Y. (2007). The dynamics of Soil degradation and incentives for optimal management in the Central Highlands of Ethiopia Ph.D Thesis, Department of Agricultural Economics, Extension and Rural Development, Faculty of Natural and Agricultural Science, university of Pretoria.

47. Udoh E. J. and Etim N. A. (2006). Cocoyam Farms in Akwa Ibom State. Nigeria. A Stochastic Production Frontier Approach. Journal of Sustainable Development in Agriculture and Environment, 2:41-48.

48. Udoh E. J. and Etim, N. A. (2008). Measurement of Farm-Level Efficiency of Waterleaf (Talinumtriangulare) Production among City Farmers in Akwa Ibom State. Journal of Sustainable Development in Agriculture and Environment, 3(2):47-54.

49. Yirga, C. T. (2007). The dynamics of soil degradation and incentives for optimal management in Central Highlands of Ethiopia. Ph.D Thesis. Department of Agricultural Economics, Extension and Rural Development, University of Pretoria, South Africa.

50. Zegeye T. Tadesse B. and Tesfaye S. (2001). Determinants of adoption of improved maize technologies in maize growing regions in Ethiopia. Second national maize workshop of Ethiopia 12-16 November, Addis Ababa, Ethiopia.

51. Zepeda, L. (1994). Simultaneity of Technology adoption and Productivity. J. Agric. Resource, Economics 19:46-57. 